\title{
Democratic imperialism and Risorgimento colonialism: European legionnaires on the Argentine Pampa in the 1850s
}

\author{
Alessandro Bonvini ${ }^{1}$ and Stephen Jacobson ${ }^{2 *}$ \\ ${ }^{1}$ Scuola Superiore Meridionale, Università degli Studi di Napoli ‘Federico II’, Largo S. Marcellino, 10, 80138, Napoli, Italy and \\ ${ }^{2}$ Departament d'Humanitats, Institut d'Història Jaume Vicens Vives, Universitat Pompeu Fabra, Ramon Trias Fargas, 25-27, \\ 08005 Barcelona, Spain \\ *Corresponding author. E-mail: stephen.jacobson@upf.edu
}

\begin{abstract}
In the wake of the Revolutions of 1848 in Europe, democratic nationalism promoted the liberation of oppressed peoples from the shackles of absolutist empires and prophesied the emergence of a cosmopolitan brotherhood of nation states. From a global perspective, however, this political culture could be imperial. The governors of State of Buenos Aires modelled plans for the White colonization of the pampas on French Algeria. They sent a Military-Agricultural Legion to the enclave of Bahía Blanca, near the Patagonian frontier, to participate in the war against the Indians. Launched as the successor to Garibaldi's Italian Legion of Montevideo, its leaders promised to bring civilization to savage lands in the spirit of Columbus and in the name of the Risorgimento. This case study offers a window into the cross-pollination of ideas concerning conquest and colonization between Latin America and Europe. Expansion and secession, empire and nation, mestizaje and racial hierarchies, cosmopolitanism and adventurism, all coexisted within an entangled republican universe.
\end{abstract}

Keywords: Foreign legions; White colonization; civilizing mission; democratic internationalism; Risorgimento

On 29 September 1856, Coronel Silvino Olivieri, commander of the Military-Agricultural Legion, was murdered by his own troops in 'New Rome', a settlement a two-day march from Bahía Blanca, one of the southern outposts of the State of Buenos Aires near the Patagonian frontier. Theoretically modelled on militarized towns in the Roman Empire, politicians had hoped that the settlement would pave the way for the White colonization of the southern pampas. Launched with great fanfare as the successor to Garibaldi's Italian Legion of Montevideo, its officers espoused a republican ethos of the State of Buenos Aires and the Italian Risorgimento while evoking the spirit of Columbus and promising to bring European civilization to virgin and savage lands. Following the murder, the legionnaires abandoned the site. Many returned to Bahía Blanca, others made their way to Buenos Aires or closer towns and a few melted into native settlements. Thereafter, the Legion remained in Bahía Blanca, and, after receiving reinforcements, joined the Army of the South in December of 1857 in an offensive against the Llaimache Indians. ${ }^{1}$

At first glance, the fate of the colony may seem unsurprising. Few authors were read with such zeal in Buenos Aires as the frequently serialized Alexandre Dumas. His Montevideo or the New Troy (1850) had publicized the defence of Montevideo (1843-51), popularized the Argentine

\footnotetext{
${ }^{1}$ For detailed and informative, though hagiographic, amateur histories, see Antonio Crespi Valls, Primer centenario de la Legión Agrícola Militar, 1856-1956 (Bahía Blanca: Municipalidad de Bahía Blanca, 1955); and César Puliafito, La Legione Italiana, Bahía Blanca, 1856. El frente olvidado del Risorgimento (Bahía Blanca: Self Published, 2006).

(c) The Author(s), 2021. Published by Cambridge University Press. This is an Open Access article, distributed under the terms of the Creative Commons Attribution licence (http://creativecommons.org/licenses/by/4.0), which permits unrestricted re-use, distribution and reproduction, provided the original article is properly cited.
} 
dictum of 'civilization versus barbarism' in Europe and depicted the caudillo Juan Manuel de Rosas as the antichrist of worldwide republicanism. The defeat of Rosas in the Battle of Caseros in 1852 brought a new generation of liberal leaders to the State of Buenos Aires, which, following the September Revolution, seceded from the Confederation of Argentina with its capital in Paraná. The city of Buenos Aires resisted a siege from December 1852 to July 1853 after which the attention of its governors turned south to the Indians and to populating 'the desert'. In retrospect, the ideologically driven elite of this revolutionary and expansionist state would have been well served by taking another gander at Dumas. In Captain Pamphile (1839), the French author had portrayed New World agricultural communities as the stuff of slave traders, swindlers and pirates.

At the time, the statesmen of Buenos Aires did not focus on the numerous experiments that had ended badly. In the heady days following the fall of Rosas and the September Revolution, and riding an economic boom that attracted immigrants, they were confident that they could replicate on the pampas a similar project of German colonization in the southern Brazilian region of Rio Grande do Sul. ${ }^{2}$ This, in turn, had been inspired by Habsburg militarized settlements on the Hungarian and Ottoman border. Around the same time, the Confederation of Argentina also launched a number of military-agricultural communities in the provinces of Santa Fe, Entre Ríos and Corrientes, while Paraguay founded 'New Bourdeaux' in the region of Chaco. ${ }^{3}$ None were very successful and most were failures. Following the death of Olivieri, dissident voices accused him of torture, tyranny and embezzlement, while his supporters claimed he had attempted to instil military discipline into rebellious recruits ill-prepared for the drudgeries of a chilly agricultural colony. He was said to have formed a governing click consisting of his brothers and fellow Neapolitans whose style clashed with the others. ${ }^{4}$ Most of the officers and troops came from Genoa and its environs, other northern Italian cities and towns and various European states. Of the original 286 soldiers and junior officers who followed 66 more senior officers into the Legion, 168 were Italian, while the others were from Germany (46), France (31), Spain (20), Latin America (9), Switzerland (6) and other European states (6). ${ }^{5}$

Inhospitable conditions, fraudulent recruitment schemes, lack of experienced farmers, poor funding and communications, the pierced charisma of authoritarian governors, leadership contests, a cacophony of languages, Indian raids, accusations of White slavery, and debauched and mutinous colonists were the reasons why such colonies failed. Following these experiments, governors and entrepreneurs in various Argentine states disentangled colonization from militarization, relocated settlements in protected zones, recruited qualified peasant families, provided adequate resources and implemented successful projects adapted to the terrain. Interestingly, a similar evolution took place in French Algeria. Following the 'June Days' of the Revolution of 1848, General Cavaignac launched a Saint Simonian project that grouped Parisian unemployed workers into colonies agricoles and put them under military discipline. Most of the original colonists died or abandoned their parcels, causing governors to implement more practical methods in the 1850 s. $^{6}$

\footnotetext{
${ }^{2}$ For a good summary of the ample German and Brazilian literature, see Jorge Luiz da Cunha, 'A Colônia de São Leopoldo: a primeira fase da colonização alemã no Rio Grande do Sul', Revista Acadêmica Licenciałacturas 5, no. 2 (2017): 37-43. For a later period, see the insightful Sebastian Conrad, Globalisation and the Nation in Imperial Germany (Cambridge: Cambridge University Press, 2010), 275-333.

${ }^{3}$ Julio Djenderedjian, Sílcora Bearzotti, and Juan Luis Martirén, Expansión agrícola y colonización en la segunda mitad del siglo XX, vol. 1. (Buenos Aires: Teseo, 2010), 235-76.

${ }^{4}$ Estanislao S. Zeballos, Callvucurá y la dinastía de los Piedra, 2d ed. (Buenos Aires: 1890), 63-7; and Crespi Valls, Primer centenario, 94-119.

${ }^{5}$ For enlisted men and officer lists for the core group of the Military-Agricultural Legion, see 'Elenco nominativo della Legión Agrícola-Militar', cartella 6, fascicolo 3, no. 138, and 'Elenco degli associati al giornale Legione Agricola', cartella 6, fascicolo 3, no. 140, Fondo Cuneo, Biblioteca dell'Accademia Nazionale dei Lincei e Corsiniana (hereafter cited as BANLC, FC).

${ }^{6}$ Michael J. Heffernan, 'The Parisian Poor and the Colonization of Algeria during the Second Republic', French History 3 , no. 4 (1989): 377-403; and Jennifer E. Sessions, 'Colonizing Revolutionary Politics: Algeria and the French Revolution of 1848', French Politics, Culture and Society 33, no. 1 (2015): 75-100.
} 
The historical interest of the Military-Agricultural Legion transcends the incidental repercussions of New Rome to the development of more mature colonization projects. The Legion regrouped under the new leadership of Antonio Susini, a friend of Garibaldi and former commander of the Italian Legion of Montevideo. It remained active in the war against the Indians and the defence of the enclave of Bahía Blanca. Its last mission occurred in September 1861 when it was called into action in the Battle of Pavón, the final armed conflict of Argentine unification. Promoted by iconic figures of European and Latin American democracy, the Legion represented the union of two schools of republican thought - the Argentine quest to populate the 'desert' with immigrant pioneers of preferred racial stock with the Mazzinian vision of a cosmopolitan brotherhood of democratic nations. These ideals were by no means contradictory but were mutually reinforcing. What is more, they were carried out by a motley group of men, some of whom styled themselves as adventurers. All in all, its history provides a window into the imperial dimensions of international democracy, the colonial aspects of the Risorgimento and the cross-pollination of ideas concerning conquest and civilization between Europe and Argentina.

The small case study contributes to three large historiographical questions. The first concerns the origins of the 'civilizing mission'. Scholars have focused on early modern European ideologies of empire in the Americas as well as cultural encounters between Western and Eastern civilizations. They have traced how nineteenth-century thinkers and propagandists distilled diverse and sophisticated Enlightenment ideas to justify the Napoleonic invasion of Egypt, the French conquest of Algeria and British rule in India. ${ }^{7}$ Missing from the analysis, however, is the nineteenthcentury Atlantic world and Latin America. For much of the century, republican Argentina carried out a similar project on the Pampa as liberal, republican and Bonapartist France undertook in the Maghreb. Moreover, the Río de la Plata was linked to Europe via trade, immigration and reverse immigration. If a republican civilizing mission crystalized during the French Third Republic and reverberated elsewhere, then surely more attention must be given to transnational republican culture. To be sure, it is necessary to understand 'civilization' as an ideological construct that was elaborated and reconfigured in global contexts rather than a doctrine articulated within the confines of Europe and imposed overseas. ${ }^{8}$ In the State of Buenos Aires, the definition of 'civilization' became so equated with a 'republicanized' and idealized vision of Europe that it was arguably more 'European' than Europe's itself.

The second subject concerns the nature of colonialism. Traditionally, scholars defined colonialism as a means by which a country established sovereignty over other peoples through the territorial imposition of religion, language, economic practices and ethnic and racial hierarchies. Recently, many have challenged this paradigm by studying how diverse polities and non-sovereign or semi-sovereign entities have spread influence, power and culture through immigration, settlement, trade, finance and diplomatic meddling. On one end of the spectrum, Italian monarchical states, led by Piedmont-Sardinia, facilitated immigration and promoted commerce and investment while steering clear of the internal ideological battles of the American republics. ${ }^{9}$ On the other end, a diverse cast of 'men on the spot' (traders scientists, soldiers, deportees) and intermediaries (consuls, businessmen and immigration companies) collaborated with politicians to launch diverse enterprises and settlements. Similar practices have been referred to as

\footnotetext{
${ }^{7}$ Anthony Pagden, Lords of All The World: Ideologies of Empire in Spain, Britain and France, c. 1500 - c. 1800 (New Haven: Yale University Press, 1995); Jennifer Pitts, A Turn to Empire: The Rise of Imperial Liberalism in Britain and France (Princeton: Princeton University Press, 2005); and Jürgen Osterhammel, Unfabling the East: The Enlightenment's Encounter with Asia (Princeton: Princeton University Press, 2018), 503-16.

${ }^{8}$ Kenneth Pomeranz, 'Empire and "Civilizing" Missions, Past and Present', Daedalus 134, no. 2 (2005): 34-45; and Cemil Aydin, 'The Ottoman Empire and Global Muslim Identity in the Formation of a Eurocentric World Order, 1815-1919', in Civilizations and World Order: Geopolitics and Cultural Difference, ed. Fred Dallmayr, M. Akif Kayapinar and İsmail Yaylaci (Lanham, MD: Lexington Books, 2014), 117-44.

${ }^{9}$ For Genoese immigration and commerce in the early decades of the nineteenth century in Buenos Aires, see Catia Brilli, Genoese Trade and Migration in the Spanish Atlantic, 1700-1830 (Cambridge: Cambridge University Press, 2016), 164-202.
} 
'colonialism without colonies', 'semi-colonialism' or even 'rogue imperialism'. ${ }^{10}$ Within this mix, the Military-Agricultural Legion was an example of 'Risorgimento colonialism', a species of semi-colonialism that also featured some rather roguish personages. Maurizio Isabella has explored how some early nineteenth-century liberal Risorgimento thinkers embraced idealized visions of the British, French and even the Ottoman empires and prophesied the future emergence of a cosmopolitan confederacy of nations sharing a universalistic ideal of civilization. ${ }^{11}$ In the 1850s, some Risorgimento democrats moved from theory to practice. They promoted settlements from Asia Minor to North Africa to Latin America, projecting an image of the Italian nation overseas.

The third body of literature explores the contours of this transatlantic democratic culture. Within this literature, little attention has been paid to conquest and colonization. Rather, most studies have focused on how progressive ideas, political networks and foreign fighters crisscrossed the Atlantic as Europe's spirit of 1848 travelled to the Americas, and the defeat of the caudillos in Latin America helped keep the flame alive for republicans in southern Europe. A number of authors have shown how immigrant 'forty-eighters' to the Americas promoted trade-unionism, abolitionism and liberalism and volunteered in the defence of Montevideo, in the US Civil War and in the Mexican resistance to the French occupation. ${ }^{12}$ In a series of fascinating studies, Guy Thomson has chronicled the rise of an insurrectional 'Democratic International' or a 'Holy Alliance of the People' that stretched from Latin America to the Mediterranean and drew its strength from cross-class alliances between elite and 'subalterns' including artisans, day labourers and smallholders. While intellectual leaders gathered in salons to discuss political theory, workers took advantage of rising wages and new consumption habits to meet in taverns, read newspapers aloud, curse the rich and powerful, and plan political action. ${ }^{13}$

This article complements these studies by examining another characteristic of this elite and popular culture, which was influential and durable, though anathematic to future democrats eager to purify their ideology from its association with race and empire. By the 1850s, many volunteers and intellectuals came to view conquest and colonization as part and parcel of the struggle of democracy against despotism, obscurantism and barbarism. Such ideas were particularly prevalent on frontiers, or, at least, in places regarded as 'frontiers', but they also reverberated in and emanated from central polities. In Algeria, European settlers were resolute republicans. They equated civilization with settlement and opposed the assimilationist policies of Napoleon III as representative of big business, large landholding and native rights. ${ }^{14}$ In a like manner, Buenos Aires liberals

\footnotetext{
${ }^{10}$ Ulbe Bosma, 'European Colonial Soldiers in the Nineteenth Century: Their Role in White Global Migration and Patterns of Colonial Settlement', Journal of Global History 4, no. 2 (2009): 317-36; Steven Press, Rogue Empires: Contracts and Conmen in Europe's Scramble for Africa (Cambridge, MA: Harvard University Press, 2017); and Anne Reinhardt, Navigating Semi-Colonialism: Shipping, Sovereignty, and Nation-Building in China, 1860-1937 (Cambridge, MA: Harvard East Asian Monographs, 2018).

${ }^{11}$ Maurizio Isabella, 'Mazzini's Internationalism in Context: From the Cosmopolitan Patriotism of the Italian Carbonari to Mazzini's Europe of Nations', in Giuseppe Mazzini and the Globalisation of Democratic Nationalism, ed. C.A. Bayly and Eugenio F. Biagini (Oxford: Oxford University Press, 2008), 37-59; and 'Liberalism and Empires in the Mediterranean: The View-Point of the Risorgimento', in The Risorgimento Revisited: Nationalism and Culture in Nineteenth-Century Italy, ed. Silvana Patriarca and Lucy Riall (Basingstoke: Palgrave MacMillan, 2012), 232-54.

${ }^{12}$ Lawrence Douglas Taylor Hansen, 'Voluntarios extranjeros en los ejércitos liberales mexicanos, 1854-1867', Historia Mexicana 37, no. 2 (1987): 205-37; Bruce Levine, The Spirit of 1848: German Immigrants, Labor Conflict, and the Coming of the Civil War (Urbana: University of Illinois Press, 1992); and Don H. Doyle, The Cause of all Nations: An International History of the American Civil War (New York: Basic Books, 2015), 58-184.

${ }^{13}$ For the 'Holy Alliance of the People', see Guy Thomson, "Democracia": Popular Liberalism in Sicily, Mexico, Spain and Colombia, 1848-1894', in Nationalism and Transnationalism in Spain and Latin America, 1808-1923, ed. Paul Garner and Angel Smith (Cardiff: University of Wales Press, 2017), 93-116; For the 'Democratic International', see Guy Thomson, The Birth of Modern Politics in Spain: Democracy, Association and Revolution, 1854-1875 (Basingstoke: Palgrave Macmillan, 2010), 67.

${ }^{14}$ Osama W. Abi-Mershed, Apostles of Modernity: Saint-Simonians and the Civilizing Mission in Algeria (Stanford: Stanford University Press, 2010), 158-63.
} 
promised to implant European smallholding in the 'desert' and, by so doing, sought to undo agreements between Indian caciques and the large cattle export interests of the caudillos. To some republicans on both sides of the Atlantic and Mediterranean, universal suffrage, freedom of press and association, free trade, abolition, judicial rights and the cult of liberty went hand in hand with White settlement, smallholding agriculture, and bringing civilization to savage lands from North Africa to Patagonia.

Although this study contributes to these large questions, the Military-Agricultural Legion was not a microcosm of the totality of global republicanism. It is convenient to envision republicanism as a garden in which the Legion shared similarities with some, but not certainly not all, of its flora. Republicanism could be imperial or anti-imperial, expansionist or secessionist, and sometimes a bundle of contradictions. The ambitions of the State of Buenos Aires had many parallels. Most notably, the 'imperial republic' of the United States - to borrow the words of Richard White - also launched multiple wars against Native Americans in the 1850s in the Southwest, the Great Plains and the Pacific Northwest after decades of relative peace. ${ }^{15}$ In Europe and in much of the southern cone of the Americas, many republicans vilified the European and Brazilian empires for repressing national liberation and popular sovereignty, sustaining serfdom and slavery, prohibiting associations and censuring the press, while looking favourably upon some of their overseas (or overland) settlements.

In contrast, many republicans in the Americas and Asia took a less sanguine view. James Sanders has observed that the Latin American public sphere resounded with invectives against European imperialism and portrayals of a decrepit continent characterized by rancid monarchies, idiosyncratic aristocratic habits and miniscule franchises. Such denunciations gathered pace in the 1860s when the French invasion of Mexico (1861-67), the Spanish annexations of the Dominican Republic (1861-65) and Peru's Chincha Islands (1864-66) and the prospect of a filibustering Confederate United States threatened the sovereignty of the young republics. ${ }^{16}$ In India, European imperialism logically received harsh treatment. As Christopher Bayly has demonstrated, Hindu intellectuals embraced democratic nationalism by founding 'Young Bengal' in the 1840s. By the 1870s, they marshalled Mazzini's Duties of Man, and romanticized the triumphs of Italian patriots, in order to promote the spiritual unity of the Indian peoples and to repudiate the liberal defence of empire as articulated by John Stuart Mill. ${ }^{17}$ With such parallels and counterexamples in mind, this study of 'democratic imperialism' represents an exploration into the imperial visage of a Janus-faced republicanism.

\section{The Legion, the State and the Indians}

Although events transpired in a corner of the world, the Military-Agricultural Legion was not some wayward experiment divorced from the mainstream. Rather, it was as an ambitious enterprise, financed by the Buenos Aires government and lauded by many of the secular saints of democratic internationalism, most famously Mazzini and Garibaldi. The principal organizers were Giovanni Battista Cuneo, the chief representative of Mazzinism in the Río de la Plata, and his colleague Bartolomé Mitre, the Minister of War who launched the Legion in 1855. Cuneo had previously lived in Montevideo where he collaborated with Mitre and other romantic literati of the 'Generation of 1837' who had formed the bulwark of Young Argentina, rebaptized the May Association. These exiles had spearheaded the intellectual opposition to Rosas. The Unitarian faction had returned to Buenos Aires where its member served as politicians and

\footnotetext{
${ }^{15}$ Richard White, 'It's Your Misfortune and None of My Own': A New History of the American West (Norman: University of Oklahoma Press, 1991), 94-108.

${ }^{16}$ James E. Sanders, The Vanguard of the Atlantic World: Creating Modernity, Nation, and Democracy in NineteenthCentury Latin America (Durham: Duke University Press, 2014), 81-135, 144-5, 151-5.

${ }^{17}$ C.A. Bayly, 'Liberalism at Large: Mazzini and Nineteenth-century Indian Thought', in Giuseppe Mazzini, 355-74.
} 
journalists in the new state. Cuneo frequented Buenos Aires associations while editing the bimonthly periodical, La Legione Agricola. In this way, Mazzini and Cuneo sought to repeat the same propaganda operation with Olivieri as they had orchestrated with Garibaldi when Cuneo had edited Il Legionario Italiano in Montevideo. ${ }^{18}$

It might seem surprising that Risorgimento elite and foreign legionnaires demonstrated such enthusiasm for conquest and settlement. Italian and other foreign legions were usually comprised of volunteers who crossed borders to fight against absolutist empires that supressed sovereignty and exerted hegemony over 'oppressed peoples'. This brand of volunteerism began with Napoleonic war veterans who fought for Latin American independence and philhellenic volunteers who travelled to Greece beginning in 1821 and 1822. It continued in civil wars in Spain and Portugal in the 1820s and 1830s, and multiple conflicts in Europe and the Americas, including Garibaldi's first overseas adventure on behalf of the independence of Rio Grande do Sul in Brazil. ${ }^{19}$ Furthermore, the Risorgimento was, at least in its origins, splenetically anti-imperial. Early theorists had pilloried the legacy of ancient Rome, which they associated with a despotic aristocracy whose thirst for conquest and riches had led to disorder and decadence. Instead, they harked back to the Italic peoples as a repository of simple customs, austere habits and harmonious social relations, and to the civic humanistic traditions of the medieval city-states as a source for republican virtue. The mention of Rome also evoked the Napoleonic empire in Italy, the legacy of which generated disagreements among patriots. ${ }^{20}$ When the 'empire' did not specifically refer to Rome or Napoleon, it always referred to the Habsburg Empire, the grand enemy of Italian unification.

All the same, by mid-century, many republicans had come to terms with empire, past and present, providing the concept did not refer to one of Europe's despotic monarchies. By the 1830s, Mazzini and his contemporaries had broken with the 'Italic model' by promoting the Roman Empire as an exalted reference for a unified nation able to overcome provincialism and regionalism. They connected its glorious imperial past with the messianic destiny of the Risorgimento. ${ }^{21}$ The French conquest of Algeria also evoked frequent comparisons to the Roman Empire and its racial hierarchies. By the 1840s, Algeria had grown from an absolutist military adventure into a liberal colonization project that was to constitute a laboratory for further expansion overseas and attract immigrants from various European states. Saint Simonian travellers, ethnographers and engineers heralded Algeria as a promised land where impoverished urban masses from different nations could relocate as yeoman settlers. They mixed romantic stereotypes of the sensual allures of the Orient with scientific studies for the exploitation of minerals and land. ${ }^{22}$

\footnotetext{
${ }^{18}$ Jorge Myers, 'Giuseppe Mazzini and the Emergence of Liberal Nationalism in the River Plate and Chile, 1835-60', in Giuseppe Mazzini, 323-46; and Lucy Riall, Garibaldi: Invention of a Hero (New Haven: Yale University Press, 2007), 33-58.

${ }^{19}$ This body of literature is immense. Some notable contributions in English, not cited elsewhere, include: Spencer L. Leitman, 'Italian Revolutionaries in the Empire of Brazil', Italian Americana 2, no. 2 (1976): 143-55; Gilles Pécout, 'Phillhellenism in Italy: Political Friendship and the Italian Volunteers in the Mediterranean in the Nineteenth Century', Journal of Modern Italian Studies 9, no. 4 (2004): 405-27; Matthew Brown, Adventuring through Spanish Colonies: Simón Bolivar, Foreign Mercenaries and the Birth of New Nations (Liverpool: Liverpool University Press, 2006); Richard Stites, The Four Horsemen: Riding to Liberty in Post-Napoleonic Europe (Oxford: Oxford University Press, 2014); Konstantina Zanou, Transnational Patriotism in the Mediterranean, 1800-1850: Stammering the Nation (Oxford: Oxford University Press, 2018).

${ }^{20}$ Maurizio Isabella, Risorgimento in Exile: Italian Émigrés and the Liberal International in the Post-Napoleonic Era (Oxford: Oxford University Press, 2009), 25, 104-5; and Anna Maria Rao, 'Republicanism in Italy from the Eighteenth Century to the Early Risorgimento', Journal of Modern Italian Studies 17, no. 2 (2012): 149-67.

${ }^{21}$ Andrea Giardina and André Vauchez, Il mito di Roma: Da Carlo Magno a Mussolini (Rome-Bari: Editori Laterza, 2000) 177-92; Adrian Lyttelton, 'Creating a National Past: History, Myth and Image in the Risorgimento', in Making and Remaking Italy: The Cultivation of National Identity around the Risorgimento, ed. Albert R. Ascoli and Krystyna Von Henneberg (Oxford: Berg, 2001), 27-76; Antonino De Francesco, The Antiquity of the Italian Nation: The Cultural Origins of a Political Myth in Modern Italy, 1796-1943 (Oxford, Oxford University Press, 2013), 159-81.

${ }^{22}$ Pamela M. Pilbeam, Saint-Simonians in Nineteenth-Century France: From Free Love to Algeria (Basingstoke: Palgrave Macmillan, 2013), 130-72.
} 
The foundation of the French Foreign Legion in Algeria also served to endow volunteerism with an imperial air, rehabilitating the spirit of the Grande Armée, which had incidentally crossed into Russia in 1812 with Germans, Poles, Italians and other foreigners comprising half of its ranks. The Foreign Legion sent satellite legions to combat absolutism during the Carlist War (1833-40) and the Crimean War (1853-56). ${ }^{23}$ Defeating Spanish or Russian obscurantism in Iberia and Crimea was deemed equivalent to fighting Bedouin hordes in Algeria, or, for that matter, Indian tribes on the Pampa.

The Military-Agricultural Legion was literally cloaked in threads of ancient Rome and contemporary Algeria. The periodical La Legione Agricola bristled with references to New Rome as a Capitoline Hill, Olivieri as a new Romulus or Aeneas and the legionnaires as world citizens from diverse European lands with Italic ploughs. ${ }^{24}$ In this vein, the poet Francesco Dall'Ongaro heralded the legionnaires as 'civilizers' who were 'pure of American blood' destined to carry out a 'new conquest of the Americas' by replacing religion with the 'sacred fire of Rome'. ${ }^{25}$ Mitre cited the French colonies in Algeria as the model for his military-agricultural colonies. ${ }^{26}$ Cuneo compared New Rome with its 'progressive agriculture' and 'military discipline' to the settlements of army veterans created by Marshal Bugeaud in Algeria. ${ }^{27}$ Most revealingly, the State of Buenos Aires outfitted the Legion in the striking (and sometime ridiculed) 'oriental-styled' uniform of the zouave troops of the French Foreign Legion, which had garnered celebrated victories in the Crimean War. ${ }^{28}$ If this was not enough to remind soldiers of their mission, Olivieri decorated his headquarters with 'six paintings of the war in the Orient'. ${ }^{29}$

Whilst the romantic attraction of virgin lands, triumphal allusions to the Roman Empire and the flamboyant uniforms of the zouave troops attracted volunteers to the Legion, Coronel Olivieri also had much celebrity cachet. His colourful biography made him famous as a budding 'hero of two worlds', a patriot of impeccable revolutionary pedigree destined to replicate the triumphs of Lafayette and Garibaldi. ${ }^{30}$ Olivieri was educated in the military academy of Nunziatella in Naples, fought in the First War of Italian Independence in Milan in 1848 and joined the Sicilian uprising in 1849. After fleeing Europe, he enlisted in the Italian Legion in Montevideo. He rose to fame as the charismatic leader of a new Italian Legion - christened the 'Valiant Legion' - that defended Buenos Aires during the siege of the Confederation. He also boasted impressive family connections. Born into a liberal family of the Neapolitan aristocracy, he married into a Bonapartist dynasty after meeting Leocadia Cambaceres in Buenos Aires. Imprisoned in Rome in 1853, Napoleon III intervened with the Pope to secure his release. ${ }^{31}$ Before leaving again to Buenos Aires in 1855, Olivieri met with Mazzini in London where they discussed the Legion and perhaps its future participation in a march on Rome. ${ }^{32}$

Had Olivieri met a different fate, the Military-Agricultural Legion might have joined Risorgimento military operations in Italy. Ostensibly, this was the plan. As Mazzini grew uncomfortable with Garibaldi's flirtations with monarchy, he contemplated the young and fiery Neapolitan as a possible 'replacement for Garibaldi' as early as $1854 .^{33}$ Once Olivieri returned

\footnotetext{
${ }^{23}$ Moises Enrique Rodriguez, Under the Flags of Freedom: British Mercenaries in the War of the Two Brothers, the First Carlist War, and the Greek War of Independence (1821-1840) (Lanham, MD: Hamilton Books, 2009), 183, 196.

${ }^{24}$ La Legione Agricola, 10 February 1856, 2, 5; and 26 March 1856, 3.

${ }^{25}$ La Legione Agricola, 24 September 1856, 3.

${ }^{26}$ Bartolomé Mitre, 'La guerra de la frontera', in Profesión de fe y otros escritos publicados en Los Debates de 1852 (Buenos Aires: Universidad de Buenos Aires, 1956), 91-101.

${ }^{27}$ La Legione Agricola, 26 March 1856, 2.

${ }^{28}$ For ridicule, see 'Colonias', El Nacional Argentino, 21 October 1856, 2.

${ }^{29}$ Postmortem inventory reprinted in Crespi Valls, Primer centenario, 138.

${ }^{30}$ Gaetano Bernardi, La vita del colonnello Silvino Olivieri (Naples: Stamperia e cartiere del Fibreno, 1861).

${ }^{31}$ Caja 15, expediente 4, Estado de Buenos Aires, Cerdeña y Dos Sicilia, Archivo Histórico de la Cancillería Argentina.

${ }^{32}$ Luis C. Caronti, Legiones italianas. Breve noticia de sus servicios en el ejército argentino (Buenos Aires: 1907), 52.

${ }^{33}$ Giuseppe Mazzini, 'A Nicolao Ferrari' (20 December 1854), in Scritti editi ed inediti di Giuseppe Mazzini. Epistolario (Imola: P. Galeati, 1929), 30, 297.
} 
to the New World, Mazzini suggested that he should be 'responsible for the military organization' of the Partito d'Azione in Latin America, destined for a mission to the Italian Peninsula. ${ }^{34}$ For his part, Garibaldi envisioned him as the commander of an expedition of Argentine and Italian patriots to the Kingdom of Two Sicilies. ${ }^{35}$ From Zurich, the distinguished exile Filippo de Boni, also took note. In 1848, this official of the Roman Republic had travelled to Switzerland with the objective to recruit foreign volunteers. He heaped praise on the legionnaires of the 'plough and arms' and foresaw the mobilization of the Legion in a future war against the Habsburgs. ${ }^{36}$

The focus on the Legion also sheds light on the global interconnections of the State of Buenos Aires. Even though the State has been often viewed as an ephemeral entity, squeezed between the end of the dictatorship of Rosas in 1852 and the national unification of Argentina in 1859, it was one of the states in Latin America where liberals had, or were soon to, triumph over authoritarian caudillos. In this sense, romantic intellectuals, such as Bartolomé Mitre, Domingo Faustino Sarmiento and Valentín Alsina succeeded where Mazzini, Kossuth and Ledru-Rollin had failed in Europe. The political elite of the new state refused to remain part of the Confederation of Argentina, depicting its president General Justo José de Urquiza, one of the richest men in Latin America, as another dictatorial cattle rancher in the image of Rosas. Wary of mass politics and sceptical of caudillo populism, this elite did not embrace the socialistic policies of 1848 . Instead, they interpreted 1848 conservatively and equated their non-violent September Revolution of 1852 with the Glorious Revolution in Britain. Nonetheless, this powerful and potentially rich revolutionary state was regarded as a pariah by European (and Brazilian) monarchies precisely because of its bold republican and expansionist pretentions. ${ }^{37}$

Domingo Faustino Sarmiento was the guiding light of the new state, and one of the most influential Latin American intellectuals of his generation. His return from Chile in 1855 to edit the newspaper El Nacional coincided with a radicalization of the State of Buenos Aires, highlighted by the appointment of Mitre as Minister of War in January and the return of Olivieri to Buenos Aires in October. In his acclaimed essay, Facundo: Civilization and Barbarism (1845), Sarmiento had articulated a vision for a 'new government', which he disseminated in a steady stream of articles in the Chilean and Argentine press. The mission of the city of Buenos Aires was to 'de-Hispanize' and 'Europeanize' an Argentina that had been dominated by caciques, gauchos and caudillos, and to turn it into a democratic nation. With respect to the pampas, it would be necessary not only to conquer the Indian caciques but also to replace cattle ranching, the lifeblood of the caudillos and gauchos, with smallholding agriculture and animal husbandry. Accordingly, the Army should refrain from fratricidal civil wars and be dispatched to the south with the mission to extend the frontier to the Colorado River. He advocated populating the southern pampas with military colonies, comprised of immigrants from northern Europe in search of land and freedom. The port of Bahía Blanca would then become the capital of a new south in which goods - produced by family farmers of European descent - could be shipped directly across the ocean without having to be driven by cart or hoof to Buenos Aires. ${ }^{38}$

Bartolomé Mitre complemented Sarmiento's Facundo with a number of influential articles published in exile and in the Buenos Aires periodical Los Debates in 1852. To Sarmiento's bucolic vision of a bountiful pampas populated by White peasant immigrant farmers, he added a messianic role for the Army. Under Rosas, local cattle ranchers had relied chiefly on cavalries of friendly Indians and locally recruited militias in order to coordinate frontier defences. In contrast, the

\footnotetext{
${ }^{34}$ Giuseppe Mazzini, ‘A Cuneo' (9 September 1855), in Mazzini, Scritti editi ed inediti, 31: 297.

${ }^{35}$ 'Lettera di G. Garibaldi', cartella 1, fascicolo 9, no. 138, BANLC, FC.

${ }^{36}$ La Legione Agricola, 24 July 1856, 2.

${ }^{37}$ For 1848, see David Rock, 'The European Revolutions in the Rio de la Plata', in The European Revolutions of 1848 and the Americas, ed. Guy Thomson (London: Institute of Latin American Studies, 2002), 125-41; and Tulio Halperín Donghi, Una nación para el desierto argentino, revised ed. (Buenos Aires: Prometeo Libros, 2005), 56-9. For a survey of this period, see James R. Scobie, La lucha por la consolidación de la nacionalidad argentina, 1852-62 (Buenos Aires: Librería Hachette, 1964).

${ }^{38}$ Domingo Faustino Sarmiento, Facundo: civilización y barbarie, 11th ed. (Madrid: Cátedra, 2016), 177, $293,369$.
} 
historian and artillery specialist Mitre strove to create a revolutionary volunteer army on the European style, believing that the army embodied the principles of the Latin American revolutions and doubled as a school for democracy by instilling discipline, self-sacrifice and republican virtue. $^{39}$ In 1855, he reorganized the Army to rely on volunteers, recruited many Europeans, converted local militias into a National Guard and drastically reduced the reliance on companies of friendly Indians. He foresaw that a division of 2000 soldiers could drive the Indians south of the Colorado River in a 'short campaign'. Immediately afterwards, he proposed to pacify the zone with a coordinated network of frontier forts and military-agricultural colonies. ${ }^{40}$ Although this plan derived from an ideological vision, it also responded to a demographic and economic reality. Given the economic potential and sparse population of the much of Argentina, European immigration companies were promoting Buenos Aires as a viable alternative for hardworking families given the saturation of the east coast of the United States, and the hot climate of other destinations such as French Algeria and Texas.

The Military-Agricultural Legion, then, was intended to pave the way for steady colonization. New Rome was to be the maiden settlement in the fertile valley of the Sierra de la Ventana, irrigated by a river system that emptied into the Bay of Bahía Blanca (see Figure 1). In consonance with Sarmiento's preference for northern Europeans, organizers sought inspiration from the German immigration schemes of Brazil and Chile. Before departing, Olivieri signed an agreement in January 1856 in Buenos Aires with Theodor Hoffman, legal representative of the businessman Daniele Levi, a resident of Montevideo. Levi's company would recruit 400 to 600 German and Danish farmers who would settle near Bahía Blanca in a sister colony protected by the Legion. ${ }^{41}$ Exuding optimism, the Buenos Aires legislature passed an immigration law on 7 September 1855, promising to distribute lands around Bahía Blanca and the southernmost fort of Carmen de Patagonés to immigrants from Europe. Accordingly, in December 1856, a few hundred men, women and children arrived in Buenos Aires from Le Havre, sent by the consul Alfredo de Dax in collaboration with French and Swiss immigration companies. By then, however, New Rome had failed and the valley of the Sierra de la Ventana remained Indian territory. ${ }^{42}$

This idealistic, if not utopian, vision generated some warranted scepticism. In Chile, Vicente Pérez Rosales, the government agent organizing German colonization in the province of Valdivia, doubted the viability of the plan. He reasoned that the only successful contemporary militarized settlements were those of Russian Cossacks in Siberia, but this system would not work against the fierce and mobile Araucanian Indians. ${ }^{43}$ The Indians, for their part, were well aware of the threat. In general, they preferred to deal with pragmatic caudillos and ranchers such as Rosas or Urquiza, knowledgeable of the harsh realities and more sensitive to the collage of customs of the frontier. Such a situation was common in Latin America, as indigenous groups often pursued alliances with oligarchic conservatives against doctrinaire liberals, who were more representative of urban interests, less tolerant of tradition, suspicious of natural hierarchies and eager to divide 'unpopulated' lands into smallholding parcels for republican farmers. ${ }^{44}$

The Indians were by no means a monolithic ethnicity nor were they homogenously 'indigenous'. Some Europeans, Chileans, Argentines and other Latin Americans lived in their settlements where mestizaje was common. The principal groups included the Ranqueles of the northern pampas who had traditionally inhabited the southern zones of the provinces of

\footnotetext{
${ }^{39}$ William H. Katra, The Argentine Generation of 1837: Echeverría, Alberdi, Sarmiento, Mitre (London: Associated University Presses, 1996), 143.

${ }^{40}$ Bartolomé Mitre, 'La guerra de la frontera'.

${ }^{41}$ Contracts reproduced in Bernardi, La vita del colonnello, 121-5.

${ }^{42}$ This created a scandal. 'El ex-consul del Estado de Buenos Aires en el Havre al pueblo de Buenos Aires', La Reforma Pacífica, 22 January 1857, 1; 23 January 1857, 1; 24 January 1857, 1.

${ }^{43}$ V.P.R., Memoria sobre emigración, inmigración i colonización (Santiago de Chile: Julio Belin, 1854), 149-50.

${ }^{44}$ James E. Sanders, Contentious Republicans: Popular Politics, Race, and Class in Nineteenth-Century Colombia (Durham: Duke University Press, 2004), 18-57.
} 


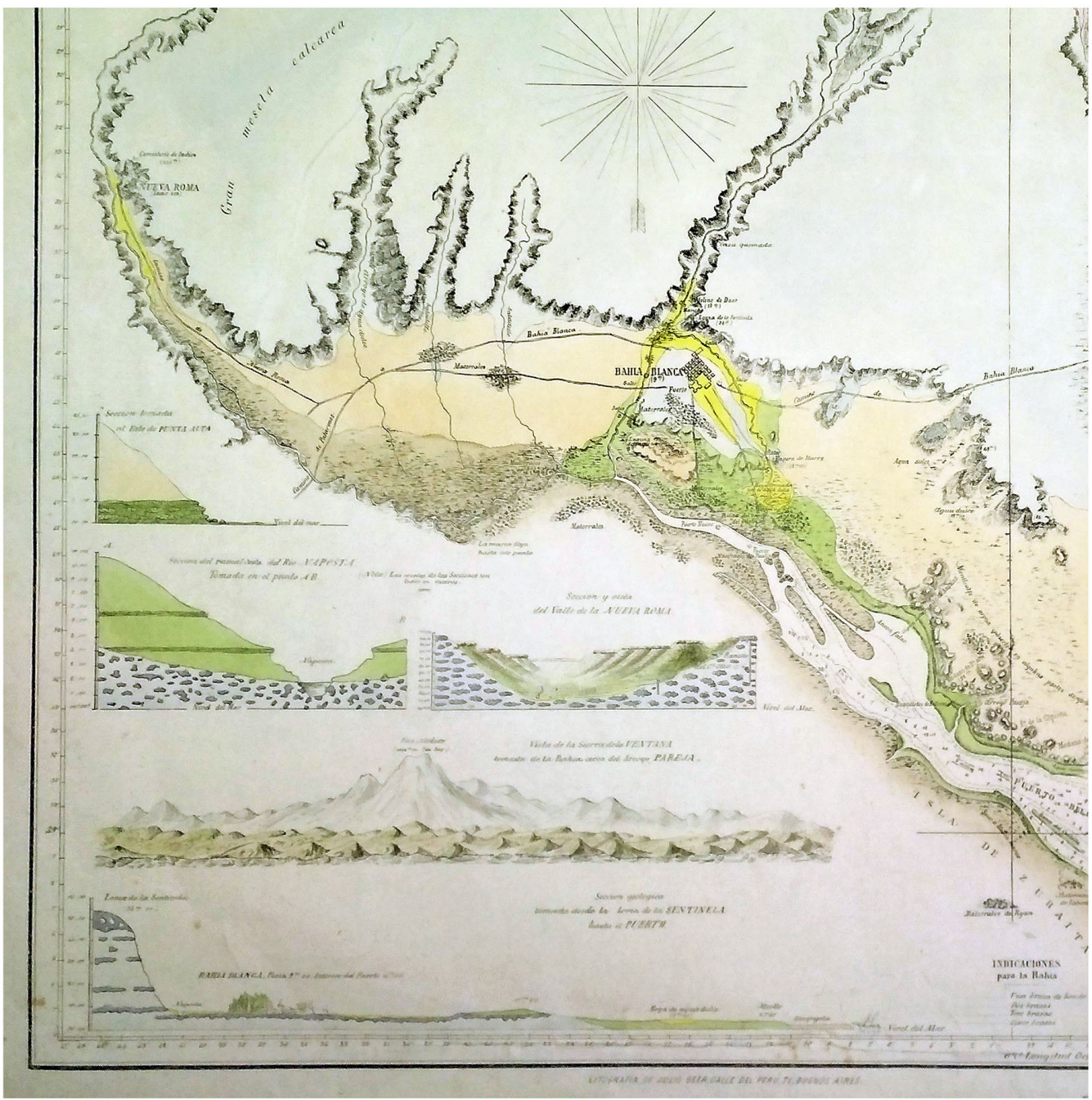

Figure 1. Detail of a Geological and Topographical Map of the Bay of Bahía Blanca and its Environs, 1857. The settlement of 'Nueva Roma' is found on the left.

(Source: Archivo Histórico, Museo Mitre, Buenos Aires, Map 639).

Mendoza, Córdoba and Santa Fe. Further south, the Tehuelches or 'Manzanaros' had their homeland was in what is today the Patagonian province of Neuquén. The 'Pampa Indians' lived on the frontier near the fort towns of Azul and Tapalqué. In the 1850s, the most powerful group was the Llaimaches who had arrived from Chile relatively recently (1841) and displaced the Boroganos, causing them to migrate towards the fort town of 25 de Mayo. Also called 'Salineros' or 'Chilean Indians', the Llaimaches settled in Salinas Grandes, a strategic zone that was rich in the key mineral of salt, essential for the conservation of meat and leather. Salinas Grandes was an entrepot for indigenous trade and a point of convergence of roads that led west across the Andes. Its control allowed the Llaimaches to dominate pampa commerce with the Arucanía region of Chile. Since the times of Rosas, the great Llaimache cacique Juan Calfacurá had led a loose Confederation of Indian tribes on the pampas. He controlled the so-called negocio pacífico, in which the Indians 
maintained peace on the frontier in exchange for rations of cattle, sheep, horses, meat, clothing and 'vices' (tobacco, herbs and alcohol). ${ }^{45}$

The State of Buenos Aires did not prevail in the frontier warfare of the 1850s nor was colonization successful at this time. ${ }^{46}$ The decade featured the periodic modification and breakdown of the negocio pacifico, which, together with the threat of colonization, provoked a number of Indian raids (malones), the largest of which carried off tens of thousands of heads of cattle and sheep and dozens of prisoners. Calfacurá's Confederation, allied with the Confederation of Argentina, inflicted defeat after defeat on the Army of Buenos Aires in 1855. Mitre's decision to rely on infantry and artillery, and his reluctance to mobilize cavalries of friendly Indians familiar with the terrain, proved to be a disaster in spite of its ideological appeal. The arrival of the MilitaryAgricultural Legion in Bahía Blanca in February 1856 made a limited impact. At first, Oliveri participated in the typical frontier tactics of raiding, kidnapping and prisoner exchange. He sent emissaries to negotiate a peace with Calfacurá of the Llaimaches (to the west) and Yanquetruz of the Tehuelches (to the south) in April 1856, which was subsequently ratified along with other accords in Buenos Aires. ${ }^{47}$ Still, the foundation of New Rome in July on the banks of the Sauce Chico blocked the corridor between Salinas Grandes and the Bay of Bahía Blanca, threatening the livelihood of the Llaimache, upsetting the territorial balance and creating tension.

In December 1857, the newly elected president Valentín Alsina mobilized the Army of the South - the Military-Agricultural Legion included - in a campaign that sought to capture the Llaimache stronghold of Salinas Grandes. Sarmiento's broadsheet, El Nacional, declared that this 'decisive blow' would 'put an end to the domination of the savage on the Pampa'. ${ }^{48}$ Salinas Grandes was 'the key to the Pampa since the time of the conquistadors'. ${ }^{49}$ Although the Army won some key battles and occupied an abandoned Salinas Grandes in February, it could not hold the position. The frontier soon returned to unstable spells of war and peace. As is well known, the 'decisive blow' did not occur until the 'conquest of the desert' of the 1870s, culminated by Julio Roca's campaign that extended the frontier to the Colorado River in 1879. In the end, Argentine colonization paralleled European projects. Grand plans for spreading civilization and transforming landscapes were largely unrealizable but served to popularize war and disseminate the ideal of a manifest destiny. Despite military failure, a puissant and persuasive republican ideological justification for conquest and colonization was firmly in place in the 1850s, interwoven with the discourse of the triumph of democracy over caudillismo.

\section{Democratic Imperialism and Risorgimento Colonialism}

For addicts of the republican press in the decade following the Revolutions of 1848, the presence of democratic volunteers from Crimea to the Maghreb to the Pampa provided hope that the triumphal march of democracy would once again arrive in Europe. In retrospect, it is paradoxical that nobody ever queried whether Amerindians might share a similar plight as Italians, Poles and other oppressed nations who anxiously sought to benefit from such a triumph. Yet 'universalistic' doctrines proclaiming popular sovereignty and natural rights, from their inception, had always excluded women, children and 'savages' deemed to have not yet achieved a mature, active or

\footnotetext{
${ }^{45}$ Silvia Ratto, 'Una experiencia fronteriza exitosa: el negocio pacífico de indios en la provincia de Buenos Aires (18291852)', Revista de Indias 63, no. 227 (2003): 191-222; and Ingrid de Jong and Silvia Ratto, 'Redes políticas en el área Auruco-pampeana: la confederación indígena de Calfucurá (1830-1870)', Intersecciones en Antropología 9, nos. 1-2 (2008): 241-59.

${ }^{46}$ The frontier has been studied in detail in: Silvia Ratto, Redes políticas en la frontera bonaerense (1836-1873): crónica de un final anunciado (Bernal: Universidad Nacional de Quilmes, 2015), 57-100.

${ }^{47}$ For the negotiations, see 'Lettera di Giuseppe Cassani', cartella 6, fascicolo 2, no. 94, BANLC, FC; and reprints of letters in Juan Calfacurá, Correspondencia, 1854-1873, ed. Omar Lobos (Buenos Aires: Ediciones Colihue, 2015), 116-23.

48'Bahía Blanca', El Nacional, 15 December 1857, 2.

${ }^{49}$ 'La campaña al desierto', El Nacional, 2 March 1858, 2.
} 
civilized state. ${ }^{50}$ If anyone needed clarity, Mazzini's providential mission to forge a cosmopolitan brotherhood of free democratic nations was reserved for those Christian cultures capable of instilling rights and duties through education and association. In 1845, Mazzini privately expressed that 'Europe had been providentially called to conquer the rest of the world to progressive civilization' to rid it of its 'retrograde and backward beliefs'. ${ }^{51}$ In 1858, he publicly announced that the futures of 'New Colombia, Africa, Australia, China and Japan' depended on the immigration of Europeans rather than 'inept Indians, black Kaffirs and Abyssinians, and yellow Mongols' ${ }^{52}$

All the same, neither Mazzini nor his Risorgimento colleagues actively campaigned for grand overseas military operations in the 1850s. In this respect, events taking place on the Argentine frontier - following the French wars against Abd el-Krim in Algeria - helped make conquest respectable. It might be expected that the Argentine quest to populate the 'desert' would have included at least a rhetorical praise for mestizaje. However, this was not the case. The Buenos Aires of Mitre and Sarmiento was not the Mexico of Benito Juárez nor even the Argentina of Rosas. Rosas' famous Desert Campaign (1833-34) cultivated his image as the 'Hero of the Desert' and helped spread an agrarian, nativist and 'Americanist' vision of Argentina identified with cattle ranching and frontier life. His supporters portrayed the campaign as a traditional military operation led by gaucho troops allied with 'friendly Indians' against 'enemy Indians'. ${ }^{53}$ The press campaigns of the 1850s, in contrast, exuded Europhilia. The State of Buenos Aires strove to implant an idealized and pristine image of a what a republican Europe might look like in the Argentine 'desert' - an image perhaps only conceivable from the perspective of overseas.

The ideological tool that allowed republicans to reconcile conquest with democracy was to depict armed conflicts - be they against European despots, Latin American caudillos or Asian, African or Amerindian emperors, chiefs and caciques - as wars between 'civilization and barbarism'. Although these concepts emerged within a sophisticated intellectual mosaic during the Enlightenment, this dialectic first appeared in Napoleonic expedition to Egypt when propagandists promised to 'liberate' the populace from their Mamluk and Ottoman pasts. ${ }^{54}$ In the 1840 s, the expression appeared as a republican mantra in the war in Algeria. ${ }^{55}$ Around the same time, Sarmiento in Facundo: Civilization and Barbarism endowed the rhetoric with political theory, equating the triumph of civilization on frontier and savage lands with the struggle of democracy over dictatorship. Dumas, for his part, transported this idea to Europe in his New Troy (1850) where it further penetrated democratic discourse. To the French author, France's Second Republic should come to the aid of compatriots 'from the Andes to the Carpathian Mountains ${ }^{56}$. Of course, these were not the only vectors. Similar notions had long been the chatter of thousands of men and women who moved, sent letters or published pamphlets around the world. In 1827, for example, the Guatemalan José Cecilio del Valle had suggested that America would catch up to the level of civilization as Europe, and together in 'adventurous harmony' would civilize Africa, Asia and Australia. ${ }^{57}$

\footnotetext{
${ }^{50}$ Lynn Hunt, Inventing Human Rights: A History (New York: W.W. Norton \& Co., 2007), 66-9.

${ }^{51}$ Giuseppe Mazzini, 'Alla madre' (7 August 1845), in Scritti editi ed inediti, 15: 92.

${ }^{52}$ Giuseppe Mazzini, 'Pensiero ed azione’ in Scritti editi ed inediti di Giuseppe Mazzini. Politica (Imola: P. Galeati, 1932), 21: 312 .

${ }^{53}$ Jorge Myers, Orden y virtud: El discurso republicano en el régimen rosista (Buenos Aires: Universidad Nacional de Quilmes, 1995), 58-72; and Raúl O. Fradkin and Jorge Gelman, Juan Manuel de Rosas: La construcción de un liderazgo político (Buenos Aires: Edhasa, 2015), 233-44.

${ }^{54}$ Anthony Pagden, Peoples and Empires: A Short History of European Migration, Exploration, and Conquest, from Greece to the Present (New York: Modern Library, 2003), 129-52.

${ }^{55}$ Philippe Darriulat, 'La gauche républicaine et la conquête de l'Algérie, de la prise d'Alger à la reddition d'Abd el-Kader (1830-1847)', Revue française d'histoire d'outre-mer 82, no. 307 (1995): 129-47.

${ }^{56}$ Alejandro Dumas, La nueva Troya. La guerra privada de Dumas contra Rosas, trans. Alejandro Waksman (Buenos Aires: Editorial Marea, 2005), 126.

${ }^{57}$ José Cecilio del Valle, Cartas autógrafas (Mexico: 1978), cited in Isabella, Risorgimento in Exile, 94.
} 
What 'civilization' meant to Latin Americans, though, was subject to conflicting interpretations. During the colonial period, Spain had erected a juridical system that protected indigenous customs, hierarchies and land tenure providing that Indian caciques submitted their peoples to evangelization. By the mid-nineteenth century, the colonial regime had disappeared, leaving the new republics and Indian communities to negotiate and reconcile traditional privileges with the requisites of individual liberty and private property. To many Latin Americans, European 'civilization' was associated with decadent aristocracies and feudal laws, while the New World republics, with their open franchises and multiracial definitions of citizenship, represented the future. It is important not to idealize either the colonial protection of indigenous communities or to exaggerate the inclusiveness of republican citizenship regimes; native rights were frequently trampled upon and overrun by the categorical imperative of juridical equality, blatant racism and sheer political fiat. ${ }^{58}$ However, it is also crucial to recognize that Latin America projected two polls of republicanism following the fall of the caudillos - one Americanist, multi-racial and inclusive and another Europhilic, racial and exclusive. Many political ideas obviously fell between these two extremes, but the officers and troops of the Military-Agricultural Legion, who disembarked in Bahía Blanca in February 1856, were not prone to nuance. Their concept of 'civilization' consisted of implanting European intensive agriculture, free labour, commerce, schooling, associational life and science.

Unlike many Latin American intellectuals, few romantics of Argentina's Generation of 1837 praised the nobility of the savage or mythologized the sophistication of preconquest civilizations. Mitre claimed that the Araucanian Indians had resisted evangelization since colonial times, so he favoured a 'crusade against the savage' that would 'exterminate' them from the Pampa. He prophesied that 'an army of landowners tied to the earth' would impose their will with the 'fire of the civilizing canon'.59 Once the Indians were pushed south of the Colorado River, they would be permitted to enter commercial relations with European immigrants in a new Patagonian world that would resemble the northern reaches of Europe with an economy based on salt mining, fur trading, logging and Merino sheep farming. ${ }^{60}$ For his part, Sarmiento equated Indians to hyenas, tigers and snakes that prayed on cattle and humans in the dark of night. He praised the United States for 'exterminating a savage people' and characterized the 'Caucasian race' as 'the most perfect, the most intelligent, the most beautiful and the most progressive' of all peoples on earth. ${ }^{61}$ Such strident opinions, expressed in El Nacional in the 1850s, were somewhat tempered by $L a$ Tribuna, which regarded Indian communities as victims of native caudillismo and advocated war followed by assimilation. ${ }^{62}$ In August 1855, La Tribuna suggested to civilize the Indians as had occurred in Mexico, Peru and Algeria where the Bedouins had begun to 'exchange their long caravans for French ploughs'.63

In Buenos Aires, opinion shapers drew inspiration from nascent European civilizing missions overseas. Above all, they invoked the French colonization of the Maghreb. To Sarmiento, Argentina shared 'same struggle between civilization and barbarism between the city and the desert that exists today in Africa'. ${ }^{64}$ The British Empire also featured. The Indian Mutiny coincided with Alsina's offensive in the latter months of 1857. The Buenos Aires press drew parallels

\footnotetext{
${ }^{58}$ The juridical protections of Indian rights in the colonial period is particularly remarkable when compared to British North America. For this, see J.H. Elliott, Empires of the Atlantic World: Britain and Spain in America, $1492-1830$ (New Haven: Yale University Press, 2006), 57-87. For the multi-racial definition of citizenship and clashes with indigenous custom, see Sanders, Vanguard of the Atlantic World, 81-135.

${ }^{59}$ Mitre, 'La guerra de la frontera', in La profesión de fe, 99.

${ }^{60}$ Mitre, 'Patagonés', in La profesión de fe, 67-79.

${ }^{61}$ Sarmiento, Facundo, 58-9; and Rebecca Earle, The Return of the Native: Indians and Myth-Making in Spanish America, 1810-1930 (Durham: Duke University Press, 2007), 114.

${ }^{62}$ 'Los indios', La Tribuna, 9 April 1857, 2; 'No más sobre los indios', La Tribuna, 10 April 1857, 2.

${ }^{63}$ 'Algunas reformas. Un proyecto para inmigración a Buenos Aires', La Tribuna, 26 August 1855, 2.

${ }^{64}$ Sarmiento, Facundo, 113.
} 
between the barbarity of the Indian rebels in Asia and the 'Indian' malones in Argentina. La Tribuna decried 'Women are raped by these corrupt assassins. After deflowering them, they oblige their sweet children and unhappy husbands, if they have not previously died, to drink the blood of their victims'. ${ }^{65}$ When the British captured Delhi, Sarmiento's El Nacional, in clear parallel to Salinas Grandes, exclaimed that the 'entire civilized world should congratulate itself on the expulsion of these barbarous and sanguinary hordes from their stronghold of treachery and deceit, the capital of the old kings of Delhi, the centre of operations of Mohamadism'. ${ }^{66}$

Politicians and journalists - in spite of the 'anti-Hispanism' of the Generation of 1837 - did not hesitate to invoke the conquest of the Americas. On 25 January 1856, the president of the State of Buenos Aires, Pastor Obligado, presided over the sending-off ceremony for the Military-Agricultural Legion at the port. In a famous harangue, he praised 'Compatriots of the immortal Columbus' and the 'illustrious conquerors of South America'. He urged them to 'conquer virgin lands from the domination of the savage in the name of world civilization and the progress of our fatherland'. ${ }^{67}$ Such characterizations were also expressed in Europe. In July 1856, the Sicilian patriot Giuseppe Carini praised the legionnaires from the pages of the Revue Franco-Italienne, encouraging them to 'bring civilization' to the New World in spirit of their 'ancestor' Columbus. ${ }^{68}$ The Spanish, in turn, equated the conquest of the Pampa with the invasion of Morocco. In December 1858, La Tribuna published a letter from the Republican Emilio Castelar who had been stirring up public opinion for what would later be bombastically labelled the 'War of Africa' (1859-60). He wrote: 'In a manner like your present situation in which you must try to dominate the Indians to push them towards a good - or bad - degree of civilization, we must subject these Moors, the remains of the barbaric races who for so long have bloodied the land and darkened its history'. ${ }^{69}$ Upon the Spanish victory in Morocco, the Argentine Press praised 'the green laurels that the mother country has picked up in Africa' and congratulated the 'great nation... that, while crossing the Atlantic, spread civilization throughout the world, leaving its blood as the seed for vigorous peoples'. ${ }^{70}$

These transatlantic, democratic and imperial dialects of the triumph of democracy over despotism, Christianity over Islam, and civilization over barbarism were drilled into the ears of the volunteers of the Military-Agricultural Legion. Upon arriving in Bahía Blanca, Olivieri promised to bring 'state security' and secure 'private property' while ensuring that 'the intelligent hand of civilized man' would defeat 'the savage who destroys everything'. 'Agriculture and art' would thereafter blossom forth from the 'virgin bosom' of the Pampa. ${ }^{71}$ Furthermore, the mission was cast within a Risorgimento practice in which immigrants and refugees formed 'colonies' abroad. Much like Juan Bautista Alberdi, one of the leaders of the Generation of 1837, had famously declared, 'to govern is to populate', Italians had also reworked the concept of 'colony' so that it meant to settle, to cultivate and to populate. A precursor to the colonial volunteer was Giacomo Durando, a Piedmontese exile in the constitutionalist army of Pedro II during the civil war in Portugal. In an address to the Lisbon parliament in August 1834, he proclaimed that the integration of foreign volunteers into the Portuguese nation would help regenerate decadent customs and virtues, improve agriculture and commerce and provide a military shield against absolutist counterrevolution. ${ }^{72}$

\footnotetext{
${ }^{65}$ 'Las inglesas en la India', La Tribuna, 22 October 1857, 2.

${ }^{66}$ 'Noticias de Europa', El Nacional, 22 December 1857, 1.

${ }^{67}$ El Orden, 25 January 1856, 2.

${ }^{68}$ Giuseppe Carini, 'Légion agricole militaire italienne dans l'Amérique du Sud', Revue Franco-Italienne, 17 July 1856, $225-6$.

${ }^{69}$ 'Correspondencia de la Tribuna', La Tribuna, 2 March 1858, 2. For more on Castelar and republican support for imperialism in Spain, see Scott Eastman, A Missionary Nation: Race, Religion, and Spain's Age of Imperialism, 1841-1881 (Lincoln: University of Nebraska Press, forthcoming 2021).

${ }^{70 ‘}$ GGentil proceder de los españoles residentes en el Paraná', El Uruguay, 3 June 1860, 1.

${ }^{71}$ 'Proclama', cartella 6, fascicolo 1, no.41, BANLC, FC.

${ }^{72}$ Grégoire Bron, 'Un manuscript inconnu de Giacomo Durando', Mélanges de l'École française de Rome: Italie et Méditerranée modernes et contemporaines 122, no. 1 (2010): 207-30.
} 
Risorgimento colonialism gained momentum following the First War of Italian Independence. Between 1848 and the mid-1850s, Greece, Anatolia and North Africa were home to diaspora colonization enterprises. Rich patriots founded 'alternative homelands' in foreign countries for émigrés. In 1849, the exile Ferrari Rodigino sought an agreement with the government of the Kingdom of Piedmont-Sardinia, requesting financial help to found a colony of expatriates in Greece. ${ }^{73}$ Later, the noblewoman Cristina Trivulzio di Belgiojoso purchased a vast track of land close to Constantinople for 5000 francs with the aim of establishing a latifundia run by patriots. ${ }^{74}$ Between 1852 and 1860, the Neapolitan radical Giovanni Mosciari sponsored an agricultural colony in Algeria, subsidized by Prince Luciano Murat. ${ }^{75}$ In this spirit, Silvino Olivieri wrote a manifesto to be distributed in Europe, although it never arrived because of his death. He invited his 'unlucky brothers' to find 'liberty and glory' by reaching New Rome, a 'reborn homeland' forged by military agriculture. ${ }^{76}$ Taken as a whole, the Italian nation was portrayed as an imperial nation, an imagined community of destiny and descent, cemented by blood and brotherhood, whose mission was to implant civilization in foreign lands. ${ }^{77}$

By the 1850s, most colonization projects, like New Rome, were directed across the Atlantic. Since the Wars of Independence, Latin America had become a leitmotif within Risorgimento revolutionary discourse - a 'promised land' of freedom and progress, a myth strengthened by the cult of Garibaldi. Monarchical governments also contemplated similar projects, albeit with different objectives. To wealthy Europeans, America was a depository for the unwanted and a solution for pauperism. To this end, Pedro de Angelis, Consul of the Kingdom of Two Sicilies to the Argentine Confederation and former pro-Rosas journalist, proposed in 1855 to transfer 6000 Neapolitan prisoners to an agricultural colony. ${ }^{78}$ Despite the mixed results of these and similar initiatives, hope burned eternal. In 1867, the radical Emilio Bosisio submitted a plan to Benito Juárez for an agricultural colony in Mexico, which, like much of Italy, had recently rid itself of its Habsburg monarch. He invited Italian farmers and workers to depart the 'rancid Europe of monarchs' to join in 'common cause' with republicans of the New World. ${ }^{79}$

\section{The Legionnaires}

Few groups have inspired such praise or provoked such anxiety as foreign legionnaires. While some have lauded their ideological purity and heroism, others have disparaged them as wanderers, corsairs or rogues in search of wages, women and plunder. Conflicting opinions abounded in the Río de la Plata. The British traveller Robert Elves described Montevideo during the siege as a 'refuge of vagabonds, discontent with all the countries of Europe' who were no more than 'mercenaries calling themselves patriots' ${ }^{80}$ Infamous on both sides of the Atlantic was the scandalous conduct of Garibaldi's Condottieri in the quaint white church of Colonia de Sacramento. They were said to have cut the throat of the statue of the Virgin of the Carmen and turned the altar into 'a table of orgies'. ${ }^{81}$ The Confederation press characterized the motives

\footnotetext{
${ }^{73}$ Francesco Poggi, Dall'armistizio Salasco al Proclama di Moncalieri, vol. 2, L'emigrazione politica in Genova ed in Liguria dal 1848 al 1857: fonti e memorie, ed. Francesco Poggi (Modena, STEM: 1957), 335.

${ }^{74}$ Cristina Trivulzio di Belgiojoso, Ricordi dell'esilio (Rome: Edizioni Paoline, 1978), 173.

${ }^{75}$ Ersilio Michel, Esuli italiani in Algeria (1815-1861) (Bologna: L. Cappelli, 1935), 91.

${ }^{76}$ Second manifesto reprinted in Bernardi, La vita del colonnello, 87-9.

${ }^{77}$ For this concept, see Josep M. Fradera, The Imperial Nation: Citizens and Subjects in the British, French, Spanish, and American Empires (Princeton: Princeton University Press, 2018).

${ }^{78}$ 'Basi per l'introduzione di sei mila emigranti del Regno delle Due Sicilie nel territorio della Confederazione Argentina', fascicolo 4754, Affari diversi della Prima Segreteria di Stato e della Segreteria, poi Ministero degli Affari Esteri, Archivio di Stato di Napoli

${ }^{79}$ 'Lettera di Emilio Bosisio', manuscrito J.15-2330, Archivo Benito Juárez, Biblioteca Nacional de México.

${ }^{80}$ Cited in Eduardo Míguez, Bartolomé Mitre: entre la nación y la Historia (Buenos Aires: Edhasa, 2018 ), 30.

${ }^{81}$ Cited in Jasper Ridley, Garibaldi (New York: Viking Press, 1976), 181.
} 
of volunteers of the Military-Agricultural Legion as 'necessity, a thirst for adventure and vice'. ${ }^{82}$ Accusations of debauchery and hedonism differed markedly from adulatory descriptions such as 'illustrious conquerors of South America', patriots of the 'plough and arms' or the 'civilized man' destined by god to make art and agriculture flourish on the 'virgin bosom' of the Pampa.

By examining the legionnaires, it is possible to appreciate the extent to which democratic imperialism had popular support and how adventurism coexisted with political ideals and practical considerations. As was the case with many agents of colonization throughout the world, officers and ordinary soldiers had mixed motives. The amateur histories of the Legion are full of laudatory biographies of officers who published poetry, founded schools, designed bridges and imbued civilizational ideals among the troops. As might be expected, elite officers and organizers balanced their ideological convictions with business interests. Most striking was the case of John Le Long, the notoriously unscrupulous recruiter for the French Legion in Montevideo, who got his start in human trafficking by provisioning maids in Paris. After the siege, he organized the shipment of French and Swiss colonists to the Colonia San José in the province of Entre Ríos and remained active in such schemes for decades. ${ }^{83}$ Cuneo, although he enjoyed a better reputation, was involved in similar enterprises. During the siege of Montevideo, he collaborated with the veteran Italian volunteer from the Portuguese civil war, Francesco Anzani. In one letter, Anzani proposed the development of 'speculation projects' for diaspora merchants and commercial agents, offering 'tools to double their financial capital' in order to garner support for the Risorgimento. ${ }^{84}$ Later in life, Cuneo worked as an immigration agent for the Argentine Republic in Italy. ${ }^{85}$

With respect to the ordinary soldier, an ample literature exists on the mixed motives of volunteers who are 'pushed' into enlisting for personal reasons and 'pulled' by ideology or the promise of wages, uniforms, arms, land and adventure. ${ }^{86}$ The foreign legionnaires of Montevideo, for example, exuded ideological zeal while also viewing volunteerism as a way to ease migration. ${ }^{87}$ It is crucial to stress that debauchery did not undermine popular republicanism. Gathering in taverns, chasing (and capturing) women and even engaging in thievery and other crimes, especially against the rich and privileged, were part of a highly masculinized political culture in which republicanism represented a libertine rebellion against the hypocrisy and femininity of bourgeois polite society. Political organizations founded upon the principles of Mazzinian cosmopolitanism that espoused Christian virtues and Kantian morals always made room for men fleeing debt collectors, police, vendettas, paternal obligations, bad marriages and government repression. It is no coincidence that Dumas, the author of the New Troy, also wrote redemptive adventure novels such as the Count of Montecristo (1844). In this tale, a group of sailors, smugglers and kidnappers from the Italian and French Mediterranean triumph over the corrupt and wellcoifed elite of the July Monarchy in Paris. Along the way, they share in the pleasures of smoking hashish and enjoying the subservient attentions of Oriental women.

Even though the State of Buenos Aires attracted many hearty and enterprising immigrant families, it was also keen to recruit 1848 revolutionaries and sympathizers, demobilized troops

\footnotetext{
${ }^{82 ‘}$ Colonias', El Nacional Argentino, 21 October 1856, 2.

${ }^{83}$ John le Long, 'El General Urquiza', La Tribuna, 26 February 1862, 1; and John le Court, 'El caballero John le Long', El Uruguay, 20 March 1862, 1-2.

${ }^{84}$ 'Lettera di Francesco Anzani', Rivista di Roma 11, no. 13 (1907): 388.

${ }^{85}$ Federica Bertagna, La stampa italiana in Argentina (Rome: Donzelli, 2009), 21-2.

${ }^{86}$ For 'push' and 'pull', see Nir Arielli, From Byron to bin Laden: A History of Foreign War Volunteers (Cambridge, MA: Harvard University Press, 2017), 66-93. See also Christine G. Küger and Sonja Levsen eds., War Volunteering in Modern Times: From the French Revolution to the Second World War (Basingstoke: Palgrave Macmillan, 2011); and Nir Arielli and Bruce Collins eds., Transnational Soldiers: Foreign Military Enlistment in the Modern Era (Basingstoke: Palgrave Macmillan, 2013).

${ }^{87}$ Mario Etchechury Barrera, 'La “causa de Montevideo”. Inmigración, legionarismo y voluntariado militar en el Río de la Plata, 1848-1852', Nuevo Mundo, Mundos Nuevos (Paris, 13 December 2012). http://nuevomundo.revues.org/64670; and “"Defensores de la humanidad y la civilización”. Las legiones extranjeras de Montevideo, entre el mito cosmopolita y la eclosión de las “nacionalidades” (1838-1851)', Historia 50, no. 2 (2017): 491-524.
} 
and even rogue wanderers. It sponsored dozens of entrepreneurial 'consuls' in European cities from Liverpool to Hamburg to Palermo. Eager to relieve Malthusian pressures and to facilitate the emigration of 'undisciplined adventurers', European governments allowed such consuls to operate as 'confidential agents' even though they did not grant diplomatic recognition to the State of Buenos Aires. ${ }^{88}$ The consuls worked with immigration companies who advertised the virtues of 'extremely high daily wages', 'the best meat at a half penny a pound', and 'where women were remarkably beautiful and where many of them wanted husbands'. ${ }^{89}$ Dumas' New Troy, sometimes used as a recruiting tool, boasted that 'Buenos Aires had the fame of having the most beautiful women in Latin America'. ${ }^{90}$ At the end of the 1850s, the Consul for Piedmont-Sardinia in La Plata, warned of the 'uncontrolled release of passports' towards Latin America. ${ }^{91}$

The Military-Agricultural Legion was comprised of many soldiers with previous experiences in legions known for their radicalism. Of the original cohort of 168 Italian soldiers and junior officers who initially arrived in Bahía Blanca, at least one-third had served in the Italian Legions of Montevideo or Buenos Aries and some had fought in the Italian Wars of Independence. The senior officers, for their part, were generally either military veterans or persons with recognized republican credentials. Some of the soldiers and officers had formed part of the 173 members of the Compagnia dei Lombardi, who left the port of Genoa in the early months of 1851 to serve in the Italian Legion of Montevideo. Of those who arrived in Bahía Blanca, it is possible to identify a handful of revolutionaries who had participated in the Milan insurrection or defended the Roman Republic in $1848 .{ }^{92}$ Another group who joined the Legion were some of the men from the British-Italian Legion, stationed in Malta during the Crimean War. Politicians in Westminster had been eager to ship them off to the New World out of fear that they might stir up insurrection on the British Isles. ${ }^{93}$ Initially promised their own Military-Agricultural Legion in Entre Ríos, they arrived in Montevideo in January 1857 in a mutinous state. According to the Confederation consul, the rebellion was fuelled by 'the arrival of some Italians who suggested that they could obtain better conditions by enlisting in the agricultural colony of Bahía Blanca'. The manifest of the ship that transported them across the Río de la Plata to Buenos Aires listed ' 100 passengers for the legion'. 94

The Military-Agricultural Legionnaires did not leave memoirs, but they are one of the few groups of volunteers where documentation makes it is possible to trace social origins, marital status and literacy rates. Practically all recruits listed their status as single, but not all styled themselves as adventurers. The Legion was not comprised of men in the most desperate of situations. This supports the idea that political motivations must of weighed heavily. Revealingly, $85 \%$ of the recruits came from skilled, semi-skilled and white-collar professions and $71 \%$ were literate. The legionnaire was, on average, more literate and from a higher social class than the average European or North American immigrant volunteer in the Army or the average immigrant to

\footnotetext{
${ }^{88}$ 'Nota del console generale Gaetano Gavazzo', no. 119, Materie politiche per rapporto all'estero, Consolati Nazionali, Archivio di Stato di Torino (hereafter cited as AST, MPRE, CN).

${ }^{89}$ House of Commons Debate, 8 June 1857, v. 145, cc. 1338-40.

${ }^{90}$ Dumas, Nueva Troya, 25.

${ }^{91}$ 'I Missione del Cav. Cerruti al Plata', busta 118, Segreteria di Stato degli Affari Esteri del Regno di Sardegna, 1799-1861, Archivio Storico Diplomatico del Ministero degli Affari Esteri.

${ }^{92}$ For lists of the Legión Valiente, see Legiones Extranjeras, Vol. 18-18-2 (May, 1853), Sala X, Archivo General de la Nación, Argentina (hereinafter cited as AGN). For the lists of the legion of Montevideo, see M. Torterolo, La Legión Italiana en el Uruguay (Montevideo: Imprenta de la Escuela Naval, 1923), 209-37; 'Relación nominal de la Compañía destinada a formar parte de la Legión Italiana en Armas en Montevideo', caja 1750, carpeta 3, Ministerio de Relaciones Exteriores, Archivo General de la Nación de Uruguay. For those of the Compagnia dei Lombardi, see 'Relación nominal de los voluntarios enganchados en esta, que salen p.a esa en el Berg.n Sardo Emilia Carolina su Cap.n D. Pedro Pertusio', no. 132, AST, MPRE, CN; and 'Nota del console generale Gaetano Gavazzo', no. 119, AST, MPRE, CN.

${ }^{93}$ C.C. Bayley, Mercenaries for the Crimea: The German, Swiss and Italian Legions in British Service, 1854-56 (Montreal: McGill-Queen's University Press, 1977), 132.

${ }^{94}$ Vol. 110, p. 218. Fondo Urquiza, AGN; and Vol. 36-8-30 (4 February 1857), Dirección Gobierno Nacional, AGN.
} 
Buenos Aires. This was not only true with respect to the legionnaires as a whole, but with respect to each constitutive nationality. ${ }^{95}$

Although the Legion began as a radical outfit under the leadership of the charismatic Olivieri, it suffered from the typical problems of other foreign legions, particularly attrition. When it left Bahía Blanca to join the campaign to occupy Salinas Grandes in the summer of 1857, only fifty soldiers and junior officers remained from the original cohort. A force that had swelled to some 600 individuals had shrunk to $240 .{ }^{96}$ Many members had rather mundane reasons for joining, and a few were even sent to finish prison sentences. ${ }^{97}$ One legionnaire was Ramali Nanjier, an illiterate manservant from India. Another was Thomas Godland, a sailor from Guernsey. The most common description on enlistment sheets, other than soldier, was 'sailor' (marinero), an occupation with low rates of literacy. ${ }^{98}$ This suggests that some men literally abandoned their ships in search of opportunity or adventure. Still, soldiers and sailors were some of the most revolutionary men of the Atlantic world. Fascinating life stories lay behind each legionnaire. One of the early volunteers was the 48-year-old blacksmith Giacomo Alighieri born in the town of Mandello on Lake Como. He signed up with his sons Giuseppe, aged 23 years, and Alessandro, aged 21 years, a blacksmith and a painter from the nearby Italian-speaking town of Lugano Switzerland. These three souls remained in the Legion even after most of the original cohort had deserted. Why did the Alighieri family move from Lombardy to Switzerland to Buenos Aires to Bahía Blanca? Unintimidated by the cold of the Patagonian frontier, were they political exiles or economic migrants or both?

\section{Conclusion}

As is often the case with foreign legions, the Military-Agricultural Legion's propaganda value outweighed its accomplishments. Following the failure of New Rome, the Legion joined the Army of the South in the campaign to occupy Salinas Grandes, but it did not distinguish itself in any key battles. Later, it proved unable to protect Bahía Blanca from an Indian raid on 19 May 1859. Following the Battle of Pavón in September 1861, some of the officers and soldiers served in foreign legions involved in the pacification of Rosario and Santa Fe. Other foreign legions formed for the Paraguayan War (1864-70).${ }^{99}$ In the end, the idealistic quest to bring pastoral tranquillity to the southern pampas through military-agricultural settlements that would attract immigrant pioneers was like Mazzini's vision of a cosmopolitan brotherhood of European nations that would spread democracy throughout the world. These ideals were never realized, but they were reinterpreted and mixed with alternative currents.

Democratic imperialism remained influential in Europe and Latin America. In 1871, Mazzini advocated invading Africa, so that Italian Tunisia, French Algeria and Spanish Morocco would together constitute a democratic recreation of the Roman Empire in which the Mediterranean

\footnotetext{
${ }^{95}$ Vols. 59-01-01 to 59-01-09 and 59-02-02-01 to 59-01-02-06, Filiaciones, Sala III, AGN. Information on social origins, marital status and literacy was gathered on 701 volunteers from Europe or North America in the Army of which 274 were in the Legion. For social origins and literacy rates of ordinary immigrants according to the Buenos Aires Census of 1856, see Jose C. Moya, Cousins and Strangers: Spanish Immigrants in Buenos Aires, 1850-1930 (Berkeley: University of California Press, 1998), 140.

${ }^{96}$ Vols. 275, 280, Lista de Revistas, Contadura Nacional, Sala III, AGN.

${ }^{97}$ For prisoners, see Crespi Valls, Primer centenario, 85, 114.

${ }^{98}$ Vols. 59-01-01 to 59-01-09, and 59-02-02-01 to 59-01-02-06, Filiaciones, Sala III, AGN. The enlistment files contain 273 Europeans where the occupation is listed (or legible). Of these, 32 were described as 'soldiers' (soldados) or 'military men' (militares) and 27 as seamen (marineros). Of these twenty-seven men, twenty-five could not sign their name and instead signed with an $\mathrm{X}$.

${ }^{99}$ Mario Etchechury-Barrera, 'Legionarios, engachados y cautivos. Apuntes para una investigación sobre las formas de reclutamiento transnacional durante la Guerra del Paraguay (1864-1870)', in A 150 años de la Guerra de la Triple Alianza contra el Paraguay, ed. Juan C. Garavaglia and Raúl O. Fradkin (Buenos Aires: Prometeo Libros, 2016), 133-60, esp. 136-39.
} 
would again become a 'Mar Nostrum'. ${ }^{100}$ By the 1880 s, Italian liberal elites had reframed Risorgimento adventurism as a vital spiritual impetus needed to build a formal empire overseas. ${ }^{101}$ A trailblazer was Giovanni Bovio, founder of the Italian Republican Party. In 1885, he spoke to the Chamber of Deputies in support of a military expedition to Massawa in Eritrea. He invoked 'the right to spread civilization everywhere' and the obligation to stop the 'barbarians' from impeding the path blazed by the 'guiding light of civic humanity'. ${ }^{102}$ In Latin America, governors in the latter decades of the century proudly proclaimed a multi-racial view of citizenship while engaging in 'anti-imperial imperialism'. ${ }^{103}$ Upon instituting policies and launching wars that supressed native rights and confiscated lands, they claimed to be carrying out a civilizing mission that contrasted favourably with the US treatment of Indians and European colonial policies.

New Rome was one of various colonies in the aftermath of 1848, which, though unsuccessful, served as a bridge to more ambitious imperial enterprises. Coincident in time was the colony of La Réunion (1856-57), a Fourierist experiment presided by Victor Considerant outside Galveston Texas. ${ }^{104}$ Even when colonies were not contemplated, organizers tapped republican networks to find soldiers for overseas missions. The Spanish Army made use of volunteer battalions recruited from revolutionary militias in Barcelona and nearby towns to serve in Morocco (1859-60) and the failed annexation the Dominican Republic (1861-65). ${ }^{105}$ Another similar project to the MilitaryAgricultural Legion was never realized, though the plans are revealing. When Lajos Kossuth undertook his famous tour in 1849 of the United States spreading 'Hungarian Fever', he conspired with Coronel John Pickett and some men of Young America to mount an invasion of Haiti to be led by a Hungarian-American Legion. The liberal credentials of this hypothetical outfit were particularly suspect, given that many of the members of Young America advocated re-establishing slavery on the island. Although this enterprise never materialized, similar ones did. European migrants and 'forty-eighters' participated in filibusterism, volunteering for Narciso López's failed Cuban expedition of 1851 and William Walker's successful conquest of Nicaragua from 1855 to $1857 .^{106}$

All in all, it is possible to piece together a history of revolutionary volunteers engaged in conquest and colonization on both sides of the Mediterranean and Atlantic. It is no coincidence that some of the most internationally recognizable figures of European democracy - Kossuth, Considerant, Cavaignac, Castelar, Cuneo and Olivieri - contemplated, advocated or implemented plans for overseas conquest and White colonization. Such enterprises took place alongside those of republicans who pushed European empires to the brink of disintegration in 1848, volunteered for battalions to defeat the Confederacy and to abolish slavery in the United States, and contributed to ousting Napoleon III from Mexico in 1867. To be sure, imperial civilizing ideals were not only compatible with but increasingly formed part of the messianic republicanism of a Democratic

\footnotetext{
${ }^{100}$ Giuseppe Mazzini, 'Principles of International Politics (1871)', reprinted in A Cosmopolitanism of Nations: Giuseppe Mazzini's Writings on Democracy, National Building, and International Relations, ed. Stefano Recchia and Nadia Urbinati (Princeton: Princeton University Press, 2009), 224-40.

${ }^{101}$ Nicola Labanca, Oltremare. Storia dell'espansione coloniale italiana (Bologna: Il Mulino, 2002), 15-56.

${ }^{102}$ Romain Rainero, L'anticolonialismo italiano da Assab ad Adua (1869-1896) (Milan: Edizioni di Comunità, 1971), 96-7.

${ }^{103}$ Greg Grandin, 'The Liberal Traditions in the Americas: Rights, Sovereignty, and the Origins of Liberal Multilateralism', American Historical Review 117, no. 1 (2012): 68-91, esp. 71.

${ }^{104}$ For this and similar colonies, see Clément Thibaud, 'Après l'esclavage. "Colonisation nouvelle” et méridien impérial en Amérique hispanique (1780-1860)', in La colonisation nouvelle (fin 18 -début $19^{e}$ siècle), ed. Marcel Dorigny and Bernard Gainot (Paris: Editions L'Harmattan, 2018), 109-52.

${ }^{105}$ Albert García Balañà, 'Patriotismo transatlánticos. Raza y nación en el impacto de la Guerra de África en el Caribe Español de 1860' Ayer. Revista de Historia Contemporánea 106, no. 2 (2017): 207-37.

${ }^{106}$ Michael L. Miller, 'From Central Europe to Central America: Forty-Eighters in the Filibuster Wars of the Mid-Nineteenth Century', in Transatlantic Revolutionary Cultures, 1789-1861, ed. Charlotte A. Lerg and Heléna Tóth (Leiden: Brill, 2018), 193-208.
} 
International. Expansion and secession, empire and nation, mestizaje and racial hierarchies, cosmopolitanism and adventurism, all coexisted within a multifarious republican universe. The Atlantic history of democratic republicanism is entangled and often disconcerting.

Acknowledgements. The authors thank Mario Etchechury and Jorge Luengo and for their comments on earlier drafts. Nascent versions of this collaboration were presented at the conference 'Global History from the South' held at the European University Institute (27 October 2018) and at Centre for the History of Ibero-America at Leeds University (30 April 2019).

Funding. Partial research funding from Spain's Ministry of Science and Innovation (Research Project Reference: PGC2018096722-B-100).

Alessandro Bonvini is Research Fellow at the Scuola Superiore Meridionale (Naples). He has been a Max Weber Fellow at the European University Institute (Florence) and a postdoctoral fellow at the German Historical Institute (Rome). He has published various articles on Risorgimento adventurers, exiles and volunteers. He is currently working on an Atlantic history of Italian patriots during the nineteenth century.

Stephen Jacobson is an Associate Professor (professor agregat) and former Director of the Institut d'Història Jaume Vicens Vives at the Universitat Pompeu Fabra (Barcelona). He is the co-editor of Endless Empires: Spain's Retreat, Europe's Eclipse, America's Decline (2013) and the author of various articles on Spain's nineteenth-century empire. His current book project examines transatlantic republican culture and migration between Barcelona and the Río de la Plata in the nineteenth century.

Cite this article: Bonvini A. and Jacobson S. 2022. Democratic imperialism and Risorgimento colonialism: European legionnaires on the Argentine Pampa in the 1850s. Journal of Global History 17: 89-108, doi:10.1017/S1740022821000152 